\title{
Author Correction: Hodgkin lymphoma
}

Joseph M. Connors, Wendy Cozen, Christian Steidl, Antonino Carbone, Richard T. Hoppe, Hans-Henning Flechtner and Nancy L. Bartlett

Correction to: Nature Reviews Disease Primers https://doi.org/10.1038/s41572-020-0189-6, published online 23 July 2020.

In this article ref. 61 was incorrect and should have been 'Greaves, P. et al. Defining characteristics of classical Hodgkin lymphoma microenvironment T-helper cells. Blood 122 (16), 2856-2863 (2013)'. The original article has been corrected.

https://doi.org/10.1038/s41572-021-00319-5 | Published online: 20 October 2021

(๑) Springer Nature Limited 2021 